\title{
THE EMOTIONAL GEOGRAPHY OF PRISON LIFE
}

\author{
Crewe, B., Warr, J., Bennett, P., and Smith, A.
}

\begin{abstract}
:
Accounts of prison life consistently describe a culture of mutual mistrust, fear, aggression and barely submerged violence. Often too, they explain how prisoners adapt to this environment in men's prisons, at least - by putting on emotional 'masks' of 'fronts' of masculine bravado which hide their vulnerabilities and deter the aggression of their peers. This article does not contest the truth of such descriptions, but argues that they provide a partial account of the prison's emotional world. Most importantly, for current purposes, they fail to describe the way in which prisons have a distinctive kind of emotional geography, with zones in which certain kinds of emotional feelings and displays are more or less acceptable. In this article, we argue that these 'emotion zones', which cannot be characterised either as 'frontstage' or 'backstage' domains, enable the display of a wider range of feelings than elsewhere in the prison. Their existence represents a challenge to depictions of prisons as environments that are unwaveringly sterile, unfailingly aggressive, or emotionally undifferentiated.
\end{abstract}

Keywords:

Prisons. Emotions. Geography. Fronting. Space.

Dr Ben Crewe is Deputy Director of the Prisons Research Centre, Institute of Criminology, University of Cambridge

Jason Warr is a PhD student at the Institute of Criminology, University of Cambridge

Peter Bennett is Director of the International Centre for Prison Studies

Alan Smith is a writer, teacher, and Senior Lecturer in English Literature at Northampton University 
Every total institution can be seen as a kind of dead sea in which little islands of vivid, encapturing activity appear. Such activity can help the individual withstand the psychological stress usually engendered by assaults upon the self. (Goffman, 1961: 68)

Accounts of prison life consistently describe a culture of mutual mistrust, fear, aggression and barely submerged violence. Often too, they explain how prisoners adapt to this environment in men's prisons, at least - by putting on emotional 'masks' of 'fronts' of masculine bravado which hide their vulnerabilities and deter the aggression of their peers. This article does not contest the truth of such descriptions, but argues that they provide a partial account of the prison's emotional world. Most importantly, for current purposes, they fail to describe the way in which prisons have a distinctive kind of emotional geography, with zones in which certain kinds of emotional feelings and displays are more or less acceptable. ${ }^{1}$ In this article, we argue that these 'emotion zones', which cannot be characterised either as 'frontstage' or 'backstage' domains, enable the display of a wider range of feelings than elsewhere in the prison. Their existence represents a challenge to depictions of prisons as environments that are unwaveringly sterile, unfailingly aggressive, or emotionally undifferentiated.

\section{RULES, ROLES AND ZONES: THE EMOTIONAL CLIMATE OF PRISON:}

While it is true that every prisoner does not live in constant fear of being robbed or beaten, the constant companionship of thieves, rapists, murderers, and aggressive homosexuals is far from reassuring. (Sykes, 1958: 77)

Descriptions of Anglo-American imprisonment often emphasise the volatility of the environment and the pervasiveness of violence (for a summary of many such studies, see Bottoms, 1999). Some studies depict a world of rampant predation and unswerving machismo (Johnson, 1987; Scraton et al, 1991; Sim, 1994; Hassine, 1999;). Violence within prisons is undoubtedly common, in the form of fights, assaults and various forms of aggression and exploitation (see, for example, O'Donnell, and Edgar, 1998; King and McDermott, 1995; Edgar et al, 2003). However, the significant overlap between victims and victimisers reported by Edgar et al (2003) implies that there might be some networks or subcultures within prisons in which violence is high, and others in which it is lower. Assaults, abuse and other such acts are targeted, with some prisoners multiply victimised but others able to remain 'above the line' of safety, particularly if they avoid the prison's informal economy, with its risks of debt and enforcement (Crewe, 2009). Bottoms (1999) notes a 'safety paradox' in prisons, whereby, despite relatively high self-reported rates of victimisation, a surprisingly large number of prisoners report feeling safe from assault. One explanation for this might be that asking prisoners to evaluate the degree to which an establishment is safe or dangerous is to misunderstand the nature and consequences of prison 'violence'. For, as Sykes suggests above, it is the possibility of violence and predation, as much as the actual level of aggression and exploitation, which many prisoners find fearful and debilitating, and it is this insidious sense of threat that means that most prisoners describe the atmosphere of most prisons as tense and enervating, regardless of whether they are personally confident of their safety.

Considering prison culture in this way directs us to the work of Thomas Hobbes, whose description in Leviathan of the 'state of nature' caused by the absence of a sovereign power is often used as a metaphor for the state of imprisonment. Most famously, Hobbes (1651/ trans. 1999) depicted life without an overarching authority as 'solitary, poor, nasty, brutish, and

\footnotetext{
${ }^{1}$ A distinction is sometimes drawn between 'emotions' (relatively undifferentiated and primitive affective states) and 'sentiments' (the determinate, social form that is given to these states) (see Gordon, 1981). For the purposes of this article, we instead adopt the former term as a shorthand for patterns of sensation, arousal and affect which are constructed and enabled within specific cultural contexts (see Bennett, 1990; Bachelard, 1994).
} 
short' (p78). But a close reading of Leviathan reveals that Hobbes is not quite portraying a state of endless warfare and aggression, but rather a constant readiness for (or fear of) warfare and aggression:

For war consisteth not in battle only, or the act of fighting, but in a tract of time, wherein the will to contend by battle is sufficiently known: and therefore the notion of time is to be considered in the nature of war, as it is in the nature of weather. For as the nature of foul weather lieth not in a shower or two of rain, but in an inclination thereto of many days together: so the nature of war consisteth not in actual fighting, but in the known disposition thereto during all the time there is no assurance to the contrary. (p77-78)

The basis for this state of tense anticipation is a form of equality, in which even 'the weakest has strength enough to kill the strongest, either by secret machination or by confederacy with others that are in the same danger with himself'. (p76). Everyone is therefore left in a state of mutual distrust, in which it is rational to launch pre-emptive attacks to defend oneself or one's property. Disputes may occur for other reasons, Hobbes notes, namely competition and glory, but even people who have no interest in using violence for gain or status will need to wield a defensive threat. The deprivation of security - to use Sykes's (1958) terminology - thus results in an emotional climate of what Hobbes calls 'diffidence', a generalised insecurity and a consumptive wariness about those with whom one is forced to live.

Prisons are generally not the anarchic, unregulated environments that Leviathan describes. Staff police prisoner behaviour, they intervene to prevent or terminate fights and assaults, and all kinds of situational and bureaucratic control measures put barriers in place to preclude or limit theft and violence. Among these, in prisons in England and Wales, are the reports that are written about prisoners by officers, psychologists and other prison staff, which contribute to decisions about progression through the system and early release (see Crewe, 2009, 2011). As we discuss below, these institutional mechanisms make prisoners more circumspect about employing violence in their daily interactions, and thereby diminish feelings of collective diffidence. At the same time, as a kind of bureaucratic gaze that looms over the prisoner- a constellation of abstract risk assessment tools and unidentifiable staff - they constitute a different threat to the self. The result is an 'omni-optical' society, in which prisoners spend a great deal of time scrutinising each other and scrutinising themselves, internalising the need to regulate their behaviour for the sake both of their peers and their guardians.

'Diffidence', as Hobbes defines it, thus seems a helpful concept in explaining many of the measures that prisoners adopt in order to survive the dangers posed by the proximity of untrustworthy strangers, the psychological threats of the environment, and the all-seeing institutional eye. Sykes's description of the prison as a 'gigantic playground - a place where blustering and brawling push life in the direction of a state of anomy' (p105) is purposely redolent of Hobbes (see Sykes, 1958: 108). But whereas Hobbes assumes that social order relies on state authority and the imposition of formal sanctions - what is sometimes referred to as 'legal centralism' - in fact, people often resolve problems not through recourse to the law, but through the application of informal norms and social controls (for an overview, see Ellickson, 1991). It is relevant, then, that Sykes's 'solution' to the inherent threats to safety and masculine ego that imprisonment entails is a collective value system - 'the inmate code' - which reduces the emotional heat of the environment, provides a shared sense of dignity, and helps the individual to ward off aggression and maintain 'integrity in the face of [institutional] privation' (p102). ${ }^{2}$

\footnotetext{
${ }^{2}$ Another outcome is that many prisoners form mutually beneficial associations in order to minimise the likelihood that they are exploited, and to alleviate some of the other deprivations of imprisonment. For current purposes, our interest is less in these social adaptations than in
} 
Sykes notes the need for prisoners to present an 'ideal of fortitude' or a 'silent stoicism', in which 'the excessive display of emotion is to be avoided at all costs' (p101), and these defensive postures have been noted in a range of subsequent studies. Jones and Schmid (2000) talk of 'conscious identity work', arguing that inmates 'suspend' their pre-prison identities and use 'impression management skills' to create false, toughened identities that allow them to interact with others; Jewkes $(2002,2005)$ notes the necessity of maintaining a 'hard' façade and a certain amount of 'controlled aggression' (2002: 56) in order to survive the rigours of imprisonment; other studies refer to impression management techniques' (Bottoms, 1999: 272), 'front management tactics' (de Viggiani, 2012), or highlight the distinction in men's prisons between public projections of hardened masculinity and private feelings of anxiety and powerlessness (see, for example, Toch, 1992; Newton, 1994).

Many of these studies reiterate Sykes's observation that 'this concept of fortitude has its roots in a vision of manhood and integrity which far transcends the prison' (p101). Either implicitly or explicitly, they connect 'front management' and the 'iron cage of [penal] masculinity' with wider forms of performative masculine culture (see, in particular, Sim, 1994; Jewkes, 2002, 2005; de Viggiani, 2012). Jewkes (2005: 48), for example, notes that: 'All forms of masculinity inevitably involve a certain degree of putting on a "manly front"'. Such accounts have often been animated by Goffman's dramaturgical metaphor, as outlined in The Presentation of Self in Everyday Life (1959): the idea of life as perpetual performance, with roles and scripts that are socially determined and enacted. Here, Goffman distinguishes principally between 'frontstage' and 'backstage' behaviour, the former being the arena in which the performance is given to a social audience, and the latter being a private or hidden region where the public performance is relinquished, breached, or contradicted.

The appeal of Goffman's framework lies partly in the fact that prisoners themselves use the term 'fronting' to describe their strategies of self-presentation. However, Goffman's framework might not be quite sufficient. First, the pose of callous indifference that many prisoners project is more than just a form of surface 'role-play'. Johnson (1987) argues that, as well as serving a practical, defensive purpose, the prisoner's 'veneer of cool, hard manliness' often reflects a 'chronically defensive' attitude (p87), rooted in deeply-lodged feelings of moral self-doubt, social rejection and psychic vulnerability (see also Newton, 1994). The prisoner's front is thus a deep defence - rather than just a postural position against the 'hurt he carries within himself' (p88), a hurt which imprisonment constantly threatens to expose.

Second, simple distinctions between a prison's public spaces or frontstage areas (where emotional expression of most forms is taboo) and its private or backstage regions, where prisoners are more able to 'be themselves', are hard to maintain. For example, cells are often described as 'private areas' (Goffman (1961:216) talks of private sleeping areas as 'personal territories'), yet many prisoners live in shared cells or are housed in dormitories, meaning that even in their most domestic environments, they may have to maintain public or quasi-public façades (Jewkes, 2005). In their description of penal space and privacy in French and Russian prisons, Milhaud and Moran (forthcoming) note that, in such circumstances, spaces of privacy, where the gaze of others can be escaped, have to be found elsewhere, sometimes in communal places, such as workshops, 'where the atmosphere turns out to be silent, everyone concentrated on the work' (p16) or where the constant clamour of machinery enables a 'retreat from the challenges of communal living', allowing prisoners a form of solitude in which they can at least be alone with their thoughts (p19).

the individual adjustments that prisoners make in order to ward off the ambient hostility of the environment. 
Other scholars have highlighted the locations within prisons where the outside and inside worlds blur and 'interpenetrate' (Farrington, 1992). Moran (2013) describes prison visiting rooms as 'liminal carceral spaces', in which prisoners (as well as their visitors - see Comfort, 2008; Codd, 2007) find themselves in a temporary limbo, between one world and the next, with the normal rules of both domains suspended. The visiting space 'represents a form of escape from the everyday life of the prison', where prisoners 'can, for the duration of the visit, suspend the immediate reality of incarceration and discuss the affairs of their family, friends and hometown' (Moran, 2013; see also Jones and Schmid, 2000). The fleeting importation into the prison of familiar food, clothing and interpersonal routines from the outside world can, for a brief period, transport the prisoner beyond their more enduring carceral space. Meanwhile, prison staff may allow exceptions to be made to normal rules and practices, again suggesting that these locations are set apart culturally from the wider institution.

In what she calls 'third spaces' within prisons (see Bhabha, 1994), Wilson (2000, 2003, 2004) describes a similar dynamic. 'Third spaces' are places or practices which are 'positioned between prison and the outside world' in terms of their discursive hue (Wilson, 2003: 294) neither spaces of autonomous action nor un-modified versions of official discourse. Through such things as humour and graffiti, the dominant institutional discourse is both 'recognised' and re-colonised, enabling prisoners to resist feelings of institutionalisation and retain (or regain) some sense of personhood. Prison rules and regulations are re-shaped, often with the collusion of staff, in ways that find creative solutions to everyday problems. The outcome is a figurative space, 'between inside and outside worlds' (2004), whose carceral texture is somewhat diminished. These spaces may be material as well as discursive. As Johnson (1987: 66) notes, prisons provide 'ecological diversity', including 'niches' or 'sanctuaries', such as workplaces, which offer prisoners 'sheltered settings and benign activities that insulate them from the mainline prison' (Johnson, 1987: 66; see also Toch, 1992), and provide microcosms of privacy, safety, support and autonomy.

Such works indicate that there are areas within prisons that cannot be characterised through a binary metaphor of front or back stages. Indeed, the terminology of 'sterile areas', 'segregation units' and 'residential areas' points to the variability as well as the importance of space and place within the prison setting. Yet very little scholarship has taken seriously the idea that, in terms of their emotional climates, prisons might be spatially differentiated. Sim (1994) notes that there are variations in masculine culture both between prisons and among prisoners, and that, within an overarching climate of hardened machismo can be found feelings of sympathy and concern. Here, then, while prisons are not presented as monolithic or homogeneous emotional domains, there is little sense of their internal complexities. An exception is found in Crawley's (2004b: 414) account of prison work, where attention is drawn to the manner in which newly recruited staff need to 'learn the organization's "emotional map" ' and express their emotions 'in clearly structured ways' (p 416). While, for the most part, this means holding in check feelings of anxiety and remaining emotionally detached from aspects of the job, it also involves sentiments such as anger and disgust being encouraged in certain 'emotional zones' within the prison, for example, among staff who have overseen sex offender treatment programmes within de-briefing rooms.

In this regard, Goffman's work remains fruitful, not so much in the form of his dramaturgical framework, but his comments in Asylums about the spatial dimensions of institutional life. For while Moran suggests that her findings contest Goffman's (1961) reading of the prison as a 'total institution', Goffman himself drew attention to the non-total nature of institutional life, in which certain non-private spaces were more normalised than others. Thus, visits rooms are described as 'a reminder to everyone in the establishment that the institution is not completely a world of its own but bears some connexion, bureaucratic and subordinated, to structures in the wider world' (1961: 98). In analysing the 'underlife' of a mental hospital, Goffman outlines in some detail the presence of 'free places' that are 'ruled by less than usual staff 
authority' (1961: 204) where 'the inmate could openly engage in a range of tabooed activity with some degree of security' (p205):

The staff did not know of the existence of these places, or knew but either stayed away or tacitly relinquished their authority when entering them. Licence, in short, had a geography ... All of these places seemed pervaded by a feeling of relaxation and self-determination, in marked contrast to the sense of uneasiness prevailing on some wards. Here one could be one's own man.' (p205-6, emphasis added) ${ }^{3}$

Concluding this section of Asylums, Goffman comments that formal organizations 'have standard places of vulnerability, such as supply rooms, sick bays, kitchens, or scenes of highly technical labor. These are the damp corners where secondary adjustments breed and start to infest the establishment' (268). In other words, and in line with the italicised sentence in the previous quotation, total institutions have internal geographies of behaviour and emotional expression, rather than a single set of what might be called - following Hochschild (1979; 1983) - 'rules of emotional display'. Hochschild argues that all institutions and organisations have informal prescriptions - 'feeling rules' - for the management of emotions, i.e. scripts that sanction what feelings should (or should not) be felt or exhibited in certain situations (see also Fineman, 1993: 21 on the 'emotional architecture' of organisations, and Bachelard, 1990). Our focus is more on the kind of 'shallow acting', 'expression management' (Gordon, 1981) or emotional performance that Goffman discusses than the deeper cultivation of feelings with which Hochschild is concerned. What we take from the latter is an interest in expectations of emotional behaviour and the factors that shape and structure them.

In the article that follows, we seek to advance current thinking about emotional performance in men's prisons in a number of ways. We begin by highlighting the dominant emotional climate of a medium-security men's training prison in the United Kingdon, detailing some alternative explanations for prisoners' forms of expression management. We note that, due to mechanisms of institutional surveillance and an entrenched sense of 'diffidence', the culture is one of tense courtesy and calibrated confrontation rather than outright violence. Second, we mark out a distinction between the 'fronts' and 'masks' that formed part of prisoners' selfpresentational strategies, drawing attention to the ways in which some prisoners had to suppress 'positive' emotions as well as control 'negative' ones. We go on to note the leakages, sublimations and positive forms of emotion that could be identified both within the prison's private areas and its more 'frontstage' locations. Finally, we describe the way that emotional norms varied within the prison, with some zones, which might be considered marginal or intermediate locations, enabling forms of emotional expression that could not be expressed elsewhere.

\section{BACKGROUND}

In 2002-03, for a period of a few months, the co-authors of this article were all present in very different roles in HMP Wellingborough, a medium-security men's training prison in the East Midlands, UK. Ben Crewe was undertaking a study of power, adaptation and social life in an English prison (see Crewe 2009), which involved him coming into the prison three or four days per week for a period of many months. Jason Warr was serving time in the establishment as a life-sentence prisoner, coming towards the end of his sentence. Alan Smith was a part-

\footnotetext{
${ }^{3}$ Likewise, in The Presentation of Self in Everyday Life, Goffman notes that there are often regions where people with different formal roles engage together with an understanding that normal rules do not apply. Thus, on ships, the galley 'is the only place where officers and men meet on a footing of complete equality' (194), functioning as a kind of 'safety-valve', where 'every man can speak his mind with impunity' (195).
} 
time philosophy teacher within the prison's education department. Peter Bennett was the prison's governing governor, the most senior person working within the establishment.

Many of the links between us formed around the prison's education department, and its philosophy class in particular. From early in his sentence, Jason had educated himself by reading widely and gaining educational qualifications. By the time that he was in Wellingborough, he was taking an introductory Open University course in the Humanities, while attending selective classes within the prison, including Alan's philosophy course. These classes were also on occasion attended by Ben, who found that the education block offered some form of sanctuary, or respite, from the hubbub of the rest of the prison and was a good place to get to know prisoners in a different way from on the wings. Ben and Jason had met early on in Ben's fieldwork period, during a survey exercise in which Jason had participated. During the subsequent course of Ben's research, they talked informally on many occasions, and more formally during two semi-structured interviews, discussing Ben's emerging thoughts and theories and Jason's wider intellectual interests.

Peter had granted Ben access to the prison in order to conduct his study, and was a sponsor and supporter of the research endeavour. Unusually, for a prison governor, he held a doctorate in anthropology, and was extremely familiar with the foundational texts of prison sociology. His $\mathrm{PhD}$ research on sacred geographies in Hindu pilgrimage and temple worship, and his writing on the cultural construction of emotion in the context of Hindu Vaishnava rituals and worship (see Bennett, 1990, 1993), directly informed his management style, which sought in a highly conscious way to forge areas where prisoners and staff could develop relationships which were empathic and creative, and foster enclaves such as the chapel, classrooms and visits hall, which emotional expression was encouraged. ${ }^{4}$

In different ways, we all recognised the potential of education to provide a refuge of sorts from the rest of the prison. Peter was a long-time advocate of educational practices in prison, and, as Wellingborough's governor, he had made broad educational provision one of his priorities. At a time when the focus in prison education was on basic literacy and numeracy, he was keen not to compromise forms of recreational education, such as art, drama, cookery and philosophy, which he believed prisoners found edifying and uplifting. During his time in post, he had appointed a writer-in-residence, who had involved prisoners in a variety of pursuits, including creative writing, talks by visiting authors, film-making and book illustration. He had invested in a kiln for the prison's pottery class, despite the misgivings of some security-staff, who were concerned that prisoners might use it to make clay impressions of keys. And he tolerated Alan's free-ranging philosophy class, which, by Alan's own admission - not least, in an occasional column in The Guardian, in which he recounted the debates that took place within it - often discussed issues that were some distance from those covered in a conventional philosophy teaching session. Alan was keen to create a space within his classroom that was as un-carceral as possible, and this was one of its attractions both for Jason and for Ben - it was a place where it felt possible to relax and recharge a little, and to be more authentic than the environment ordinarily made possible.

Although we did not recognise it explicitly at the time, each of us also felt, to some degree, that we lacked 'colleagues' within the prison. Either we were the only person in our position in the institution (Ben, Peter), or we were unusually committed to a certain form of pedagogic activity (Jason, Alan). Despite our very different positions in the institutional hierarchy, we saw in each other some characteristics that transcended these divisions. Yet we were all constrained by the formal roles that we occupied, and although keen to exist beyond them, it was difficult to shake off the 'reserve' that defines most prison interactions and is to some degree the focus of this article.

\footnotetext{
${ }^{4}$ Bennett's 1990 chapter represented a significant contribution to a volume on emotional constructionist theory at a time when it was a relatively new direction in sociology.
} 
In the period since Ben's fieldwork ended, we have remained loosely in contact, mainly in the folds of professional practice. Peter moved on from Wellingborough to become governor of HMP Grendon, and remained in touch with Ben as a prisons researcher. When Jason was coming towards the final months of his sentence, he was invited by Ben and colleagues to attend an academic conference at the University of Cambridge on 'The Effects of Imprisonment', leading to an enduring relationship of social and intellectual friendship. Having gained an undergraduate degree from London School of Economics, Jason was accepted onto the Cambridge MPhil programme in Criminological Research, and is now undertaking a $\mathrm{PhD}$ under Ben's supervision. Jason also remained in touch with Alan as friend and mentor, and it was at an evening seminar on prisons at which Jason was an invited speaker that Ben and Alan resumed contact having spent a number of years without contact.

These details are worth elaborating because they help explain the unusual genesis of this article. In 2010, Ben contacted the other authors of this article to suggest that they all participate in a session at the British Society of Criminology's annual conference, at the University of Leicester. Titled 'Reflections on boundaries, relationships and power in prison', and in a well-attended session, each of us spoke from the particular perspective that was available to us during our time at Wellingborough, and in the period following the conference, we agreed that it would be worth us trying to write up our contributions. Creating a coherent argument has required substantial revision of our conference papers, which talked in quite different ways about the themes of the session. But what all of our papers shared from the start was an emphasis on the way that certain areas of the prison - its education department, specifically - allowed and enabled relationships, power and identity to function in ways that were different from in its main residential regions and workplaces. The article that follows seeks to extend this insight, drawing on the interviews and observations undertaken by the first author during his time in Wellingborough (see Crewe 2009). These interviews did not ask specifically about the spatial organisation of prison life, but in addressing issues of identity and adaptation, they elicited numerous comments about the emotional adjustments and performances that the environment necessitated, and the ways that they differed within different zones of the environment.

\section{THE EMOTIONAL GEOGRAPHY OF PRISON LIFE}

Among the main explanations offered in the research literature for the culture, in most men's prisons, of tense machismo and vigilant emotion management are the prisoner's psychological need to re-establish his sense of masculine self-esteem (what we would call compensation), his need to develop a persona which saves him from exploitation (what we would label protection), and the benefits that can be gained, in a place where status and resources are scarce, from developing a reputation for aggressiveness (what we would call competition). De Viggiani (2012) emphasises the 'survival' functions of 'front management', while Jewkes notes that 'physical jostling for positions of power and status ... is perhaps especially visible in prisons because they are such blatantly status-depriving environments' (2005: 53). Interviews with prisoners in Wellingborough most often pointed to the protective functions of emotional self-control - the risk that displays of fear or hurt would be interpreted as signs of weakness, which could leave prisoners open to ridicule and exploitation:

I lock certain things away yes, because I don't want to open up to certain people. [...] because I see that as a weakness and I don't want people to see my weaknesses. (Ian)

It wouldn't look very good if you broke down in tears in the middle of the yard, or anything like that. It would be frowned upon. You'd get the piss taken out of you really. (Rhys) 
As well as shoring up feelings of diffidence, and safeguarding prisoners from the predation of their peers, emotional control was also an internal defence - a means of coping. Many interviewees highlighted the need to 'block out' or control their emotions in order not to 'crack up' (Ellis), 'lose the plot' (Brian), or be overpowered by feelings of weakness and distress, particularly in relation to events outside the prison over which they had almost no control:

You have to hold it in and be strong, and deal with it. [...] You just need to shut off, really, and get it out of your mind. Because at the end of the day, there's nothing you can do about it while you're in here. You just need to get it out of your mind.

(Connor)

It's heart-wrenching, being away from your kids and your Missus and things like that. But you have to do it. So you have to change yourself in certain aspects. [...] You just have to try not to let that side of things get you down, and try not to think about your kids that much. It's your mind that will fuck you up whilst you're in here, when you're thinking about things all the time. [...] You can sit there and get yourself down, and probably cry every night, cry yourself to sleep. [...] But you can't let that happen. (Leon)

The norm against emotional incontinence also had a collective coping function. Occasional displays of emotion were deemed acceptable if they were the outcome of bereavements or if they related to children (e.g. serious illnesses, custody issues). But to unload your emotions perpetually was unwelcome. As Nathan noted, 'you know full well you can't go unburdening yourself emotionally over and over and over again'. To do so was proscribed both because it placed a burden on other prisoners and because it reminded them of the personal troubles that they were trying to suppress:

You have to hide your feelings from everyone. You don't open yourself up. You don't want someone's pity. They've all got their problems as well. I don't want to be sitting listening to their problems day in, day out. And I don't want them to feel that they're sitting there listening to my problems. (Ewan)

In relation to prison officers, Crawley (2004a, 2004b) notes that when performers 'corpse' their lines, their embarrassment disrupts the entire collective performance. All members of a performance-team rely on each other to maintain the performative projection. Individually, prisoners certainly acknowledged that they were all complicit in a culture of mutual masking: 'I'm fully aware that people exist from behind a mask', said Nathan, 'There's going to be a certain thickness of barrier there'; 'everyone's got a certain barrier', said Connor. Making reference to a prisoner he knew prior to his sentence, Kyle's comments highlighted all the more clearly the collective effort required to maintain a shared emotional performance:

It's just men, isn't it, macho bullshit. It's like Joe. Out there he's a good bloke, family man, top geezer. In here he has to put on a little bit of front to save face. I know that, he knows that, people that know him know that. We all know. We obviously don't verbally mention it. (Kyle)

Here, then, prisoners testified to the need to control their forms of emotional expression in relation to each other, primarily through the presentation of appearances that were hardened or aggressive. However, most prisoners also recognised the risks of overheating emotionally, or appearing angry or confrontational, because of the way that this might be interpreted by the institution. Emotional control was necessary to prevent prisoners from getting into trouble and making their sentences more difficult:

So do you have to control your emotions in here? 
Yes, to a certain degree, I think you do. [...] Like showing signs of anger: in society, it's accepted, it's not a problem as long as you're maintaining that control. But I'm more careful in prison, because it's perceived in a different view. So I do take precautions. [....] I have to maintain a - a little front, I suppose. It's like - I've bitten on my anger (Tommy)

If you let things aggravate you you'll blow up, you'll be put down the block on basic, you'll do your bird hardcore, you don't want that for yourself, you want your bird as easy and light as possible. (Wilson)

Sometimes you've got the hump and you know you could go and shout at someone or have a go at an officer, you've got to control that. (Ellis)

Prisoners' awareness of institutional oversight thus limited their postures and practices of aggression. Some prisoners warned against precisely the kind of presentational strategies that others recommended:

If you're pumping iron every day, the screws look at you nervously and that can have a bad effect. I've seen people get shipped out of jails just for being big and tough looking. (Stephen)

In this respect, prisoners had to walk a tightrope of impression management, between appearing excessively passive and needlessly aggressive. Prison conflicts were dangerous both to ignore and to pursue, creating a highly strained culture of coiled but controlled aggression. Most prisoners wanted to avoid confrontation without losing face, and employed pre-emptive strategies in order to do so. Experienced prisoners in particular modelled a form of tense courtesy, in which they were careful to avoid giving anyone a reason to precipitate conflict (i.e. by being respectful of personal space, and dealing carefully with interpersonal friction) at the same time as communicating their willingness to defend themselves. ${ }^{5}$ Other prisoners engaged in a form of calibrated confrontation, with threats made in ways that communicated assertion without really demanding reaction. Thus, prisoners warned each other - 'stay out of my way' or 'don't speak to me' - slammed doors, and often mouthed off in front of their peers without taking further action. As one prisoner noted, these threats were more common than full confrontations: 'Instead of just going straight at it, they seem to like warn people a lot more' (Seb). As suggested here, then, considerable effort went into the management and social presentation of personal emotions.

\section{'Masking' and 'Fronting'}

The language of 'masks' and 'fronts' is widespread in accounts of men's prisons. Jewkes (2005: 52) states that: "Wearing a mask" is arguably the most common strategy for coping with the rigors of imprisonment, and all prison researchers will be familiar with the sentiment that inmates feel it necessary to adopt a facade while inside'. However, it may be helpful to draw a distinction between these two strategies. Drawing upon Hochschild's (1979) work, 'fronting' can be considered a form of evocation, 'in which the cognitive focus is on a desired feeling which is initially absent', while 'masking' represents a form of suppression, 'in which the cognitive focus is on an undesired feeling which is initially present' (1979: 561). In the prison context - and in relation to expression- rather than feeling-management - this is the difference between cultivating or presenting a version of the (emotional) self that is inauthentic, and concealing or holding in a version that is authentic. Defined broadly, the former might entail prisoners exaggerating their criminal potency, wealth and sophistication,

\footnotetext{
${ }^{5}$ These prisoners noted that, as a result, among long-term prisoners, there was a greater level of superficial politeness in prison than there was among people in the outside world.
} 
promoting legends-of-the-self, constructing themselves as highly volatile ('nutters') or liable to use weapons ('tool-merchants'), or building up their bodies to communicate aggressive potential. In contrast, 'masking' is more defensive, requiring that one stifles or contains traces of fear, pain, weakness and vulnerability (anything that appears 'feminine') (Johnson, 1987; Scraton et al, 1991; Thurston, 1996, Sabo et al, 2001).

These processes of emotion control were more conscious, and involved more everyday management, for some prisoners than for others (although, for most prisoners, they were not the kinds of rational strategies that Hobbes suggested) Some reported that they 'locked up' their feelings at the point at which they were imprisoned, or talked of going on 'on autopilot' for the duration of the sentence (what Hochschild might call 'deep acting'):

I think it's just automatic sort of thing when you come into prison, you know what I mean, you know you're coming to prison, you know you're going to be in this environment. [...] It's just something you automatically do. (Ian)

A lot of people, even me, sometimes I don't even realise I'm doing it, it's just subconsciously you do it, your mind switches, you've got part of your brain that's designated for when you come to prison and it just turns on. (Kyle)

When you come in here your emotions are cut off. [...] Everyone's emotions are in all these little boxes, on a box shelf when you come in, you park it beside the TV or near the cupboards, then when you're coming out you take them back out again, and you resort to those emotions that you've got, [...] Basically, they're on hold. (Colin)

Other prisoners were less able to simply sever their emotional nerve endings (Jewkes 2005), and instead described a perpetual - and often painful (see Liebling and Maruna, 2005: 6-7; Jewkes, 2002, 2005) - process of public self-management and private release:

I don't show no signs of weakness, no. You can't show no weaknesses. If someone cusses you, you cuss them back. You don't let somebody say you're a fucking idiot, or, you know, 'are you some kind of poof?' or something like that. You have to say: 'What's your problem, mate? You're more of a poof than I am, look at what you're wearing', stuff like that. [...] It is hard to be like that $24 / 7$ for however many years. When I'm in my cell on my own I don't cry or nothing. But I look out of the window, and I probably do feel like crying. (Seb)

I put a mask on, to hide the pain, so I try to have a laugh to bury that pain, and when I'm back in my cell I take that mask off and the pain is there again. (Sid)

When you get behind your door you're a different person. You're someone else. [...] You do put on a mask, you do have a mask, yeah. (Gavin)

As suggested here, many prisoners described the conventional distinction between 'frontstage' and 'backstage' locations. Luke reported that 'The only real time you get to relax is when the door's shut, locked, and you're on your own in that cell'. Others talked of being able to let their feelings out when listening to music or watching television in their cells: 'When you get locked up behind the door that's it, your feelings can come out again' (Ian).

Here, the emphasis is on the restraint and discharge of negative emotions. But as well as controlling feelings of pain, loneliness and vulnerability (i.e. 'negative' emotions), prisoners also described the need to regulate and suppress emotions - or aspects of character - that were more positive. A number of interviewees explained the difficulty of not being able to express warmth or show their 'caring side' (Ronan): 
In prison yes, there's a lot I've got locked away inside me, you know what I mean, I won't open up them doors until I get outside.

What sorts of things?

Well, the kind of care and affectionate, loving person I can be when I'm out there with my mum (Ian)

Are there parts of your character that you can't express?

Yeah. I'm quite a caring person. But I can't really sit down and talk to someone and say 'how are you feeling?', because it's all male, and people will think 'what the fuck's he doing?'. That's pretty hard. [...] A lot of my emotions are not in use. Which emotions?

Love. I can't show love in here, do you know what I mean? I can't be caring.

There's a lot of hate I feel, not towards inmates in general, just towards - because I'm inside and not out there. I hate that.

So it sounds like you're saying that the nice emotions that you have in life, they get stored away. And the bad emotions -

They're more prominent. [...] You have to block them off, yes. You learn not to have any emotions really. You've got to try and stop them. (Ross)

Some prisoners reported having to stem feelings of excitement about the possibility of early release, out of concern for those in less fortunate circumstances, or because being seen to care excessively about such matters could in itself be interpreted as a form of weakness (an inability to deal with prison life; or an indication that one was willing to kowtow to the institution in order to speed one's release). As a result, prisoners often had to maintain an appearance of cool indifference to their institutional circumstances. In effect, then, imprisonment dulled and narrowed the positive end of the affective spectrum, as well as amplifying its negative frequencies. It forced prisoners both to be more emotionally toughened and less emotionally generous than they felt themselves to be.

\section{Leakages and sublimations}

So far, we have outlined the ways that, in the prison's main public and residential spaces, a significant amount of emotion management was required to maintain the smooth flow of everyday life. Diffidence, and the consequent fear of appearing weak, pervaded social relations, attaching themselves to mundane interactions. Requests to borrow goods, such as toiletries, or more assertive demands for small quantities of tobacco, functioned as tests of nerve or character. Prisoners who betrayed their fear or too willingly acceded were vulnerable to exploitation. Such tests, and the modes of impression control that they demanded, were particularly significant in certain areas of the prison, such as the residential wings and prison workshops, where prisoners were most 'on show' to their peers.

Most outlets for the expression of pain and distress were private:

I've got a vulnerable side to me. I've got a really soft side to me. I'm an emotional person. And if I've got a problem, twice a month, I have to cry. It's standard. I have to cry, just to let the tension out. [...] If I don't cry, I'm going to go fucking nuts. I can't let that... [...] I don't like people to see that. (Zack)

Some outlets took private, and visceral forms, while leaving public scars. Prisoners who selfharmed talked of the emotional functions of cutting the skin - its capacity to remind them that their feelings still existed, or to liberate their emotions from within: 'all that stress and tension, it flowed out with the blood' (Fin). Many prisoners reported that they channelled aggression and relieved anxiety through physical exercise: 
I take it out down the gym, working out and doing the weights and that, yeah. Make sure I get all that aggression out. I really get into it real hard. And all the frustration I've gathered over a couple of days or over a couple of months, I take it all out in the gym. (Cameron)

However, the prison's taut state of collective affective control was sometimes punctured by moments when emotions leaked or erupted more visibly. Some prisoners channelled their feelings into culturally acceptable forms, for example, 'smashing up' their cells or engaging in highly visible outbursts of anger on the wings. Others struggled to keep their emotions in check even within public locations, for example, breaking down after difficult phone calls. Here, one prisoner's defensive reflections on such circumstances illustrate the efforts required by some prisoners to control their feelings, and the importance of doing so:

I don't care about showing emotion. I've never had a problem with it.

But you wouldn't come out of the cubicle [on the occasion when you were crying, after a difficult phone call]...

Yes, I'd come out of the cubicle. I don't care man. If anyone [says anything] then I'd fucking knock them out. Then they know I'm a man. I'll show I've got emotions. [...] I'm going to have a fucking breakdown or something if I've stored it all up. If there's something to fucking go on [about] - I don't care, man, I'll go on about it. It don't bother me. It don't bother me at all.

You've got to leave your emotions behind, some people say.

Yes, you're right. You are right. And that is - I don't care. I don't feel any weaker. That makes me a man. I'm showing my emotions at the end of the day. That's all I see. If you think I'm a pussy, prove me a pussy, because I've just fucking cried.

Emotional disclosure also occurred in bounded, semi-private arenas - within intense dyadic friendships, among cell-mates, within small friendship groups, or with trusted members of staff - often in ways that were partially controlled:

If I've got too much emotion like where I'm feeling under stress from working, or I feel like crying, or whatever, then I will. I'll cry. I'll put my music on, I'll listen to something, and I'll just let it out.

Always behind your door?

Yeah. Yeah. A few times I've done it in front of people. You know, it's been that much that I've had to let it go.

In front of other cons?

Not in front of other cons, no. [...] I've been talking to the Health Care staff. [...] A friend of mine who I went to see, I talk with sometimes. But I don't really show any of the tears side of me. He's seen me when I've been down. (Den)

I'm not ashamed to say there's times when I really miss my son. It puts a lump in my throat and tears in my eyes. But that's through myself. For no-one else to see.

Would you not be able to show that more publicly?

In front of a certain person. [...] There might be one or two people in your little clique that - the need arises and you could help them, fair enough. (Brian)

Despite ostensible claims that kindness, emotion and intimacy were absent from prison life, as suggested above, many prisoners in fact exposed their vulnerabilities within limited circles, soliciting advice on personal relationships, and seeking kindness and support from trusted associates.

In other respects, emotions were secreted within the prison's public discourse. Since it was a place where strength could be built and demonstrated, the gym was a place which seemed to exemplify the prison's intense emotional regime. De Viggiani's (2012: 278) fieldwork notes 
report the atmosphere of the prison gym as 'intimidating ... with a distinctly macho atmosphere'. Yet, in the ways that prisoners 'spotted' for each other, in their mutual support and encouragement, it was also possible to discern barely sublimated forms of intimacy. ${ }^{6}$ In other forms of physical activity, such as football matches, prisoners likewise seemed to convey intense and physical forms of camaraderie. Certainly, the vivid and joyful ways in which prisoners engaged in collective exercise, and the sheer amount of physical horseplay among younger prisoners, pointed to submerged emotional sentiments. Likewise, some prisoners publicly denied that they had close prison friendships, often disputing in front of each other that their relationships had substance. But their descriptions and daily practices waking each other up with cups of tea, knocking on cell walls to communicate goodnight wishes - were nothing if not intimate, and they suggested a more complex emotional topography than most accounts of prison life have suggested.

\section{EMOTION ZONES}

Many leakages and deviations from the prison's dominant feeling rules occurred in areas that cannot be characterised as private or backstage areas. These were marginal spaces or intermediate zones where many of the normal rules of the prisoner society were partially or temporarily suspended, permitting a broader emotional register than was possible in its main residential and most public areas. Any attempt to map the social and emotional terrain of the prison needs to take into account these locations.

One such space in Wellingborough was the visits room, where prisoners showed forms of warmth and tenderness that were taboo on the landings. For some prisoners, visits offered the only opportunity to display authentic feelings and show warmth:

When my family come every other week that's the only time I can show my true emotions, give my baby brother a kiss or give my dad and stepdad a hug, and talk about family life, where in here you don't give no one a hug, you don't show them kind of feelings to anyone. (Ronan)

The emotional landscape of the visits room was palpably different from most other areas of the prison. Here, men held their children and touched their partners with tenderness, longingly embraced family members and friends, and openly displayed joy and affection, as though their emotional identities had been resuscitated en route from the wings. ${ }^{7}$ Some were visibly upset as their visitors left, or sat in silent contemplation, their stolidity contrasting with the animated tone of a few minutes earlier. Uniformed staff too seemed softened by the emotional microclimate - as Earle (2012) notes, the presence of children partially transcends some of the normal terms of staff-prisoner engagement. On returning to the wings, the emotional displays of the visits room were not subjects of public discussion. To mock someone for showing vulnerability with their children or for being tearful with a partner was not generally acceptable. Behaviour observed in the visits hall seemed to be disqualified information:

\footnotetext{
6 'Spotting' in weightlifting is assisting someone to undertake an exercise safely, often in a way that enables them to lift a greater amount than they would be able to on their own.

${ }^{7}$ This is not to say that all prisoners were authentic in their emotional displays in this location. Some reported still having to mask their true feelings, in order to provide reassurance to their visitors:
}

You can't show your family that you're down, or anything like that. You've got to show that you're coping, like I try and have a laugh with them and that. And to show them that I'm the same person out there that I am in here. So I try and make them laugh, do the best you can.

So you're not putting on a front when you're in visits? Or are you?

A little bit, I am. [...] I can't let them know this is getting me down (Joey) 
acceptable in context, and barred from use in maliciously deriding other prisoners. In this respect, the visits hall was a sacred space of sorts.

Wellingborough's classrooms also harboured alternative emotional climates. In cookery lessons, where commensality was encouraged, prisoners shared food and complimented each other's efforts, in terms that were much more generous than those found on the prison landings. Ingredients were exchanged without the strict borrowing rules that applied on the wings. In pottery classes, there was an open camaraderie, as men praised each other's efforts, swapped tips, and shared pride and disappointment in their produce. Aesthetic appreciation could be vocalised without embarrassment. Warmth and emotion blossomed temporarily, nurtured by a female staff member who took on an explicitly maternal role. In sociology lessons, prisoners relaxed into student identities that allowed them to express hesitancy in their views, mock their own prejudices, and disclose certain kinds of personal details. Again, these acts struck a sharp contrast with the tone of the wings, where the terms of public conversations were those of certainty and bravado. As one prisoner said, 'I think people come to education for a bit of release, [from] The behaviour bullshit and the language bullshit, and the stories bullshit'.

Likewise, in the prison's philosophy class, discussions of religion and politics took place between prisoners with wildly different perspectives without tension or reprisal. In a range of environments, then, kindness, generosity and emotional disclosure were permitted, and there was some transient escape from the emotional privations of incarceration. Indeed, when prisoners talked about the value of educational activities, they spoke as much about its role in providing mental and emotional release as its practical benefits. One prisoner described his experience as follows:

When [the teacher] was reading Anthony and Cleopatra I was standing on the banks of the Nile, sounds and smells, I can close my eyes and I'm there. It's an escape, [...] it's opened up a whole new world, emotions I never knew I had. (Alfie)

Asked what art achieved for him, Den provided a similar explanation:

It doesn't keep my mind in prison. I have to sit and think about things that are outside, that I've seen outside. Let's just take for example, objects, say - a jug, a glass, you don't see things like that in here. So you've got to open your mind to think about, what does this look like? [...] A lot of people's minds tend to slow down here because they haven't got much new, incoming information. It's very limited. So it's helped me progress quite a lot. [...] If I can't do my art work I'm lost. I'd be running around like a raging lunatic. (Den)

As expressed here, educational activities enabled certain forms of emotional experience (as well as emotional expression). In Goffman's terms, these were 'removal activities', 'sufficiently engrossing and exciting to lift the participant out of himself' (Goffman 1961: 67; see also Jewkes, 2004 re in-cell television).

The prison chapel was described in a similar way, as an island of respite. In the terms of one interviewee: 'It's a different atmosphere. The people there, they're more friendly towards you, they just talk to you differently and I reckon they listen a bit more'. Noah explained that the chapel was:

....an outlet from prison. It's the only place really I tend to find people from outside coming in. And to me it's a break from the routine. You go up the chapel and you get people coming from Northampton or Wellingborough. So you have a chat, and it's just a breath of fresh air. And then, boom! You're back in reality on the wing. (Noah) 
A few points are worth highlighting here. First, in Noah's terms, the wings represented the 'reality' of imprisonment, with alternative emotional zones offering only temporary relief from the essential qualities of the environment. Prisoners who mixed beyond their normal cliques and hierarchies in these spaces relapsed into more stratified arrangements almost as soon as they left them. Relations were friendly but they were not friendships, and they rarely endured beyond these locations. In other words, it was possible, within some zones of the prison, to be a different kind of person, but the environment still placed limits on the nature of the relationship that might be formed within it (see Crewe2009).

Second, these intermediate zones required cultivation in order to be less prison-like. Much of this cultivation reflected a different 'philosophy' (or theology) of the self among education and chaplaincy staff. ${ }^{8}$ By treating prisoners as students, worshippers or workers - using their first names, and addressing them as individuals rather than abstract units - these personnel created places where the fundamentals of power, liberty and authority could, for brief periods, be put aside. To maintain these alternative cultures, civilian staff had to play with, subvert or offer alternative displays of authority from those found elsewhere in the prison. They brought in minor treats, like biscuits, which symbolised care. They disclosed more about their lives than was strictly allowed, binding prisoners into a contract of mutual candour and humanity that they then met with each other, albeit within limits. They often let prisoners call them immediately by their first names, and asked not to be called 'gov' or 'miss'. They made clear their interest in the personal advancement of the people they taught, imparting a sense of care, and a concern for the future, that was often absent from the wings. Even when education staff had misgivings about prisoners' motives or post-release intentions (which they often expressed to their colleagues), as part of their professional ideology, they celebrated success and reinforced positive aspirations. They allowed their authority to be challenged, in ways that officers rarely did, and deliberately distinguished themselves from uniformed staff by joking with prisoners about their colleagues' more militant style. Some distanced themselves from the formal authority of the prison, by de-emphasising the fact that they carried prison keys and could 'write up' prisoners for disciplinary infractions. ${ }^{9}$ They also downplayed their own professional authority - often feigning uncertainty as a pedagogic strategy - while sometimes allowing prisoners to 'run' the class. At the same time, they used their distinctive professional skills to model legitimate authority: they instructed rather than ordered, and sought respect through stature and respect rather than fear, status or command.

Perhaps most importantly, civilian staff and volunteers brought in from the outside world forms of 'ordinary discourse' that were filtered out to a greater extent on the wings, in part because interactions with officers were much more superficial. Arguably, places like the visit rooms and chapel crossed the boundaries of public and private, bringing in prisoners' external emotional lives or bringing out their private hinterlands (Moran2013; Comfort2008).

Alongside the regulation of their own emotions, the 'emotion work' that some civilian staff were undertaking involved nurturing emotional expression in others, developing their empathic capacity, and creating a safe space for collective disclosure through benign control on behalf of the group (rather than some external authority). Participation in the kinds of

\footnotetext{
${ }^{8}$ With thanks to Alison Liebling and Ruth Armstrong for this turn of phrase.

9 "In the corner of my classroom there is a bit of electronic kit up on the ceiling. I've no idea what it is but whenever things look like getting out of hand or someone seems to be on the brink of a wild indiscretion I point at it and say to it: 'Have you got that?' Or if I have gone too far in some hysterical denunciation of Capitalism one of the men might say: 'You know this is all being recorded don't you?' It stops our mouths with laughter. It is our way of placing at arm's length the necessary authority of the prison establishment, our way of stating to each other that the establishment's authority is neither welcome nor necessary in our classroom" (Smith, in progress)
} 
moral conversations that occurred within many of the education classes - from philosophy to basic literacy - required prisoners to lift their masks of studied indifference and allow buried vulnerabilities to come to the fore. One prisoner provided the following description of the impact of the prison's philosophy class:

$[\mathrm{X}]$ is a sensible lad but he's very hot-headed, he's got a short fuse [...]. He recently started philosophy classes, maybe he'll get some common sense and understanding of people's emotions and circumstances. [...] Through the philosophy, just common sense thinking, normal thinking patterns. [I've] learned to respect people for what they are, and respect their point of view. [In Alan's class] People have got the chance to give their opinions, and I like the respect shown to other people in the class - say a certain man has got an opinion, [you] sit and listen to him voice his opinion. (Alfie)

Finally, it is significant that education occupied a kind of 'third space' (Wilson2003), which permitted a form of sanctioned resistance. Prisoners who got involved in educational activities were enabled and supported by the institution, credited for their engagement with its aims, and often seen as model prisoners. Yet educational activities were experienced by prisoners as intensely personal, and educational achievements were 'owned' by the individual prisoner. Those who felt somewhat hostile to the prison system, and did not want their successes to be co-opted by it nor their commitment to be derided by other prisoners, found in education a middle-way. As Nathan commented: 'It's somewhere where, as a prisoner, you can advance yourself as an individual while advancing yourself within the prison system'. Here, then, it was possible for prisoners to forge a space that was comparatively free from the oppressive oversight of their peers on one side and the institution on the other. Within limits, and only temporarily, spaces emerged for a more authentic presentation of emotion and selfhood.

Diffidence is diminished in parts of the prison system which are less 'deep' (see King and McDermott1995) - that is, where one finds non-custodial personnel and shards of the outside world. In such places, prisoners are put in touch with disapprobation otherwise suppressed parts of themselves, while providing audiences for whom masking and fronting are unnecessary or counter-productive. Bible reading and prayer, sociological discussion and philosophical debate, creative activity, and contact with families, both encourage and require prisoners to put aside their normal postures and expose attitudes and emotions that are normally withheld. And whereas - to return to the Hobbesian allegory - prisoners normally submit to the higher authority of the institution, or to powerful prisoner groupings, to ensure some form of order and to counter-act diffidence, in education, religion and artistic activity, they find alternative normative systems, and somewhat transcendental, sources of meaning, comfort and psychological safety.

\section{Conclusion}

There is scope for a much more detailed spatial analysis of prison culture, which recognises a multitude of normative and emotional domains and describes the transitional moments from one to another, as character is masked and modified. This might resemble Goffman's work on impression management in The Presentation of Self in Everyday Life, and might draw on Foucault's comments on the spatial inscription of power. Our suggestion is that the study of penal spaces could pay much more attention than is usual to the social architecture of different penal spaces - comparing, for example, the cellular, standardised and linear nature of the wings (cells, queues, etc) with the more open, circular and intimate arrangement of classrooms. It would recognise that, in some prisons, such as high-security establishments, where prisoners are more circumspect both of their peers and of institutional power (Liebling et al 2012), there may be less space to open up emotionally, and more risk in doing so. It might demand particular kinds of research methods, such as the shadowing of prisoners (and staff) as they move between different stages. And it would need to explore the possibility that the overall cartography of the prison looks different depending on where one is located in the 
institutional hierarchy: perhaps more vertical for senior managers, and more horizontal for prisoners - the next gate, the next room, and the wall that keeps them in.

\section{References}

Bachelard G (1994) The Poetics of Space. Beacon Press: Boston, Massachusetts.

Bennett P (1990) 'In Nanda Baba's HouseThe Devotional Experience in Pushti Marg Temples', in Lynch O (ed.) Divine Passions: The Social Construction of Emotion in India. Berkeley: University of California Press

Bennett P (1993) The Path of Grace: Temple Organization and Worship in a Vaishnava Sect. Hindustan Publishing Corporation, Delhi.

Bhabha H (1994). The Location of Culture. Oxon: Routledge

Bottoms A (1999) 'Interpersonal violence and social order in prisons', in Tonry M and Petersilia J (eds) 'Prisons', Crime and Justice: A Review of Research, 26, 205-281.

Codd H (2007) In the Shadow of Prison: Families, Imprisonment and Criminal Justice: Cullompton: Willan.

Comfort M (2008) Doing Time Together: Love and Family in the Shadow of the Prison. Chicago: The University of Chicago Press.

Crawley E (2004a) Doing Prison Work: The Public and Private Lives of Prison Officers. Cullompton: Willan.

Crawley E (2004b) 'Emotion and performance: prison officers and the presentation of self in prisons', Punishment and Society, 6(4): 411-427.

Crewe B (2009) The Prisoner Society: Power, Adaption and Social Life in an English Prison. Oxford University Press.

De Viggiani N (2012) 'Trying to be something you are not: Masculine Performances within a prison setting', Men and Masculinities, 15(3), 271-291.

Earle R (20120 'Who's the daddy? Ideas about fathers from a young men's prison', The Howard Journal of Criminal Justice, 51(4), 387-399.

Edgar K., O'Donnell I and Martin C (2003) Prison Violence: The Dynamics of Conflict, Fear and Power. Cullompton: Willan.

Farrington K (1992) 'Modern prison as total institution: Public perception versus objective reality', Crime and Delinquency 38(1), 6-26.

Fineman S (ed) (1993) Emotion in Organizations. London: Sage.

Foucault M (1979) Discipline and punish: The Birth of the Prison. New York: Vintage Books, Random House.

Goffman E (1961) Asylums: Essays on the Social Situation of Mental Patients and Other Inmates. Harmondsworth: Penguin.

Goffman E (1959) Presentation of Self in Everyday Life. New York, NY: Anchor Books. 
Gordon SL (1981) 'The sociology of sentiments and emotion', in Rosenberg M and Turner R (eds) Social Psychology.New York: Basic Books.

Hassine V (1999) Life Without Parole: Living in Prison Today. Los Angeles: Roxbury Publishing.

Hobbes T (1651/ trans. 1999) Leviathan. Originally published: London: Printed for Andrew Crooke, 1651. | Prepared for the McMaster University Archive of the History of Economic Thought, by Rod Hay

Hochcschild A (1979) 'Emotion work, feeling rules, and social structure', American Journal of Sociology, 85(3), 551-575.

Hochcschild A (1983) The Managed Heart: The Commercialization of Human Feeling. Berkeley: The University of California Press.

Jewkes Y (2002) Captive Audience: Media, Masculinity and Power in Prisons. Cullompton: Willan.

Jewkes Y (2005) 'Men behind bars: 'Doing' Masculinity as an adaptation to imprisonment', Men and Masculinities, 8(1), 44-63.

Johnson R (1987) Hard Time: Understanding and Reforming the Prison. Pacific Grove, CA: Brooks/Cole Publishing.

Jones R and Schmid T (2000) Doing Time: Prison Experience and Identity Among First-Time Inmates. Stanford: Jai Press.

King R and McDermott K (1995) The State of Our Prisons. Oxford: Clarendon Press.

Liebling A and Maruna S (2005) The Effects of Imprisonment. Cullompton: Willan.

Milhaud O and Moran D (forthcoming 2013) 'Penal Space and Privacy in French and Russian Prisons' in Moran D, Gill N \& Conlon D (eds) Carceral Spaces: Mobility and Agency in Imprisonment and Migrant Detention. Ashgate, Farnham.

Moran D (2013) 'Between outside and inside? Prison visiting rooms as liminal carceral spaces', in GeoJournal.

Newton C (1994) 'Gender Theory and Prison Sociology: Using Theories of Masculinities to Interpret the Sociology of Prisons for Men', The Howard Journal of Criminal Justice, 33(3),

193-202.

O'Donnell I and Edgar K (1998), 'Routine victimisation in prisons', The Howard Journal of Criminal Justice, 37(3): 266-279.

Sabo D, Kupers T and London W (eds) (2001) Prison Masculinities. Philadelphia: Temple University Press.

Scraton P, Sim J and Skidmore P (1991) Prisons Under Protest. Milton Keynes: Open University Press. 
Sim J (1994) 'Tougher than the rest? Men in prison', in Newburn T and Stanko E (eds), Just Boys Doing Business, London: Routledge.

Sykes G (1958) The Society of Captives: A Study of a Maximum-Security Prison. Princeton, NJ: Princeton University Press.

Thurston R (1994) ‘Are You Sitting Comfortably? Men's Storytelling, Masculinity, Prison Culture and Violence', in Mac an Ghaill M (ed), Understanding Masculinities, Buckingham: Open University Press.

Toch H (1992) Living in Prison: The Ecology of Survival. New York: The Free Press.

Wilson A (2000) 2000 'There's no escape from third-space theory: Borderland discourse and the in-between literacies of prison' in Barton D, Hamilton M, Ivanic R (eds) Situated Literacies, London: Routledge.

Wilson A (2003) 'Researching in the third space - locating, claiming and valuing the research domain, in Lillis T. and Maybin J. (ed.) Language, Literacy and Education: A Reader. Milton Keynes: Open University Press.

Wilson A (2004) Four days and a breakfast - time, space and literacy/ies in the prison community' in Leander K and Sheehy M (eds.) Space Matters: Assertions of Space in Literacy Practice and Research. New York: Peter Lang. 